УДК 621.31

DOI https://doi.org/10.32838/2663-5941/2021.3/36

\title{
Чернюк А.М.
}

Українська інженерно-педагогічна академія

\section{Кирисов I.Г.}

Українська інженерно-педагогічна академія

Черевик Ю.О.

Українська інженерно-педагогічна академія

\section{АНАЛІЗ ПЕРСПЕКТИВ РОЗВИТКУ СИСТЕМ РОЗПОДІЛЕНОЇ ГЕНЕРАЦЇ̈ ЕЛЕКТРОЕНЕРГІЇ В УКРАЇНІ}

У статті розглянуто сучасні тендениї розвитку світової та вітчизняної енергетики, сучасний стан та напрями розвитку систем розподіленої генераиї, щъо базуються на альтернативних джерелах живлення.

Проаналізовано проблеми, які виникають під час побудови систем електропостачання з розподіленою генерацією. На застосування РГЕ можуть вплинути такі обмеження: постачання природного газу, щиільність електричних і теплових навантажень, стійкість функціонування електроенергетичної системи. Можливість упровадження розподіленої генерації енергї̈ визначає ї̈ конкурентоспроможність щодо централізованих систем і в цій перспективі залежать від багатьох чинників: рівня тарифів на приєднання до електричних і теплових мереж; принципів формування тарифів на електроенергію і тепло, тобто від співвідношення тарифів на електроенергію і тепло і вартості палива; практичної реалізації заходів щьоо недискриміначійного доступу до електричної мережі і до постачань природного газу; розвиненості ринку енергетичного устаткування (із його обслуговуванням); темпів розвитку економіки краӥни загалом і конкретних регіонів; протекиіоністської політики держави.

Проаналізовано світовий досвід із побудови та експлуатачії електричних мереж із розподіленою генерацією. Нині у багатьох краӥнах світу разом із розвитком иентралізованого енергопостачання все активніше підтримується тенденція широкомасштабного переходу до РГЕ, яка має перевагу більшої конкурентоспроможності.

Проаналізовано можливості енергетичного потенціалу енергоносіїв систем РГЕ в Україні. Для України під час реалізації завдань щодо широкомасштабного використання енергії відновлюваних джерел для РГЕ дуже важливим є встановлення енергетичного потенціалу кожного з видів ВДЕ на всій території України.

Проаналізовано нормативно-законодавчу базу у сфері впровадження та підтримки екологічно чистої генерації електричної енергії в Україні.

Ключові слова: розподілена генерація, Smart Grids, енергоносії, енергетичний потенціал, альтернативні джерела енергії, «зелений» тариф.

Постановка проблеми. Сучасними трендами розвитку вітчизняної та світової енергетики є демонополізація та децентралізація енергетичних ринків і систем. Із розвитком альтернативних джерел живлення з'являється все більше суб' єктів енергетичного ринку, які мають подвійне призначення. Тобто можуть виступати у ролі як споживача електричної енергії, так і іï джерела залежно від енергетичного потенціалу поновлюваних джерел живлення. Суттєвим недоліком генерації альтернативними джерелами є слабка прогнозованість виробітки електроенергії та неможливість управляти цим процесом із заданою точністю та відповідно до бажаного графіка електроспожи- вання. Тому аналітичне дослідження провідного світового досвіду побудови надійних енергетичних систем на базі об'єктів розподіленої генерації та аналіз енергетичного потенціалу різних альтернативних джерел живлення $є$ актуальним у сучасних умовах.

Постановка завдання. Метою статті є проведення аналізу перспектив розвитку систем із розподіленою генерацією та оцінка енергетичного потенціалу первинних джерел енергії для екологічно чистої генерації.

Завдання дослідження:

- провести критичний аналіз сучасного стану розвитку систем із розподіленою генерацією; 
- проаналізувати можливості побудови надійних систем електропостачання на основі об'єктів розподіленої генерації 3 важкопрогнозованими показниками виробітки електричної енергії

- оцінити нормативно-правову основу розвитку систем розподіленої генерації в Україні.

Виклад основного матеріалу дослідження. Розподілена генерація енергії (далі - РГЕ) - це виробництво енергії на рівні розподільної мережі або на стороні споживача, підключеного до мережі [1-3]. Загалом, «розподілена» генерація - це виробництво електричної енергії за місцем ii споживання. Відсутність розгалуженої мережі виключає втрати на передання електричної (теплової) енергії (за наявності великої кількості споживачів, що виробляють електричну та теплову енергію для власних потреб та направляють їх надлишки в загальну мережу).

Розподіленими генераторами енергії можуть бути когенераційні установки (далі - КГУ) малої і середньої потужності, які дозволяють понизити витрати на виробництво енергії на $40 \%$, досягти великого ефекту застосування паливних ресурсів і оптимального використання встановленої потужності. Упровадження малої розподіленої генерації енергії визначає іiі конкурентоспроможність щодо централізованих систем і в цій перспективі залежать від багатьох чинників :

- рівня тарифів на приєднання до електричних і теплових мереж;

- принципів формування тарифів на електроенергію і тепло, тобто від співвідношення тарифів на електроенергію і тепло і вартості палива;

- практичній реалізації заходів із недискримінаційного доступу до електричної мережі і до постачань природного газу;

- розвиненості ринку енергетичного устаткування (з включенням його обслуговування);

- швидкості формування економіки країни загалом і конкретних регіонів;

- протекціоністської політики держави.

Залежно від умов і чинників можливі різні сфери застосування малої розподіленої генерації енергіï, а саме:

1. Застосування РГЕ тільки для нових споживачів.

2. Використання технологій РГЕ для перетворення в ТЕЦ дрібних газових котельних.

3. Використання технологій РГЕ для перетворення в ТЕЦ великих котельних, що працюють на природному газі.

4. Перехід споживачів від централізованого електро- і теплопостачання на застосування технологій малої РГЕ.
5. Застосування РГЕ для покриття напівпікової і пікової частин графіка навантажень і як резервної потужності за умов спільної роботи з централізованою генерацією.

- На застосування РГЕ можуть вплинути такі аспекти:

- забезпечення природним газом;

- щільність електричних і теплових навантажень;

- стійкість функціонування електроенергетичної системи.

Інтеграція РГЕ в мережі забезпечує значні перспективи їх застосування поряд із централізованими системами. Можливість роботи РГЕ як єдиної $з$ централізованими джерелами мережу на індивідуальних споживачів створює передумови для інтеграції централізованого й ізольованого (децентралізованого) виробництва енергії [4; 5].

Огляд світового досвіду. Наразі у багатьох країнах світу (поряд із розвитком централізованого енергопостачання) все більш активно підтримується тенденція широкомасштабного переходу до РГЕ, яка має перевагу більшої конкурентоспроможності. Водночас кожна із систем має свою сферу застосування, в якій найбільше виявляються ії переваги $[6 ; 7 ; 8]$.

За минулі роки результатом розвитку поновлюваної енергетики стала зміна традиційної моделі функціонування електричних мереж у низці країн i регіонів. Новітні концепції впровадження розподіленої генерації вимагають більш досконалих систем управління і вирішення питань щодо застосування нових технологій підвищення надійності електромереж, ефективних систем акумулювання енергії та підвищення якості електроенергії. Безперервний пошук напрямів розв'язання проблем підвищення надійності та ефективності розподільної генерації дає можливість знайти спосіб мінімізації втрат під час передавання електроенергії, особливо в умовах широкого впровадження вітрової та сонячної генерації.

В електромережах Німеччини з високою часткою вітрової та фотоелектричної генерації були проведені дослідження щодо впливу розподіленої генерації на втрати електроенергії, які довели, що під час зростання частки мереж низької напруги сумарний рівень втрат електроенергії знижується лише до певного рівня насичення локальними генерувальними джерелами. Спираючись на це, темпи та обсяги розвитку розподіленої генерації мають бути зумовлені відповідними техніко-економічними розрахунками.

У США експлуатується близько 12 млн установок малої розподіленої генерації (одиничною 
потужністю до 60 МВТ) загальною встановленою потужністю понад 220 ГВт, а темпи іiі приросту становлять близько 5 ГВт у рік. Сумарна частка РГЕ в США не перевищує 5\% від показників у галузі. Представництва компаній BMW, Apple, Google, Wall-Mart i Kroger свої потреби в електроенергії задовольняють за рахунок використання різних видів генерації (на газі, біогазі, паливних елементах і сонячній енергіï). Так, наприклад, компанія Kroger зуміла заощадити за минулий рік 160 млн доларів.

У Данії будівництво об'єктів малої енергетики визнане одним із найбільш багатообіцяючих шляхів розвитку енергетики і підтримується державною програмою. У Данії планується перехід на поновлювану енергетику до $33 \%$ до кінця 2021 року і повна відмова від викопного палива до 2050 року. Окрім численних приватних будинків, що проектуються з використанням поновлюваних джерел енергії, в Свропі активно діють програми 3 проектування «екологічних поселень», що підтримуються державою та регіональною владою.

У Японії після аварії на АЕC «Фукусіма-1» втрата довіри японців до централізованої системи енергопостачання стала цілком очевидною. Нині в Японії найбільш популярними автономними джерелами електроенергії $€$ сонячні батареї та паливні елементи. Паливні елементи встановили у своїх будинках більше 40 тис. японських сімей. Попит на це устаткування в Японії стрімко зростає. Показовим є також досвід Китаю, який намагається не відставати від лідерів. У країні особлива роль відведена сонячній енергетиці, а також енергії вітру. Китай планує довести до 2050 року розмір виробництва енергії з альтернативних джерел до $40 \%$ у загальному енергетичному балансі країни. Міністерство енергетики Китаю затвердило новий план, який передбачає доведення потужності вітряних електростанцій до кінця 2021 року до 100 ГВт [9].

У Німеччині у межах федеральної землі БаденВюртемберг узялися до впровадження проекту енергомережі з розподіленою генерацією Smart Grids силами енергетичного концерну EnBW за підтримки Технологічного інституту в Карлсруе. Метою проекту є створення мережі з розподіленою генерацією в повнофункціональному складі: виробництво, постачання споживачеві, керування споживанням, а також тарифікація і облік. Дотепер випробовувалися лише окремі елементи таких мереж, повномасштабний проект є цілком інноваційним. Важливим аспектом у процесі реалізації проекту є робота зі споживачем. Концерн EnBW активно просуває інноваційні рішення серед своїх потенційних споживачів-користувачів Smart Grids. Для реалізації проекту концерн вже віднайшов потрібну кількість споживачів, які бажають першими використовувати всі переваги мереж із розподіленою генерацією.

У планах концерну EnBW - побудова єдиних стандартів інформаційного обміну між усіма окремими елементами мережі і всіма пристроями, що входять до складу Smart Grids, а саме:

- генератори (вітро-, сонячні тощо), встановлені в межах домогосподарства;

- пристрої тарифікації та обліку - інтелектуальні електролічильники;

- побутові прилади.

Наступним етапом буде створення аналогічних регіональних Smart Grid iз розподіленою генерацією й об'єднання їх у єдину енергосистему Німеччини.

Франція також реалізує два проекти у сфері Smart Grid. Першим проектом є розумні лічильники інтегровані із засобами управління мережами у Ліоні. Другим проектом є створення окремої регіональної системи розподіленої генерації 3 інтегрованими об'єктами відновлюваних джерел енергії (ВДЕ) та Smart-управлінням мережею [10].

Аналіз енергетичного потенціалу енергоносіїв систем РГЕ в Україні. До тенденцій упровадження РГЕ, які мають низку потенційних переваг та перспектив у світовій енергетиці майбутнього, слід зарахувати:

1. Істотне зменшення витрат у мережах (в Україні витрати в мережах становлять близько $10 \%$ електроенергії під час транспортування).

2. Суттєве зменшення «витрат природи» на анулювання масової шкоди від великих виробництв, які підривають природні захисні механізми.

3. Відмова від викопного палива, що дозволить значно скоротити забруднення навколишнього середовища та кліматичні зміни.

4. Здешевлення продуктів ВДЕ, по-перше, завдяки науково-інженерним інноваційним технологіям, по-друге, внаслідок відшкодування початкових затрат на будівництво та обладнання [10].

Із досвіду країн $\mathrm{CC}$ та світу можливо зрозуміти, що впровадження РГЕ у дійсні енергосистеми здійснюється в три етапи.

Перший етап - упровадження РГЕ до дійсних енергосистем. Україна перебуває лише на першому етапі, коли країни $Є С$ уже пройшли цей етап.

Другий етап - формування децентралізованої електромережі, яка буде працювати разом із 
локальною енергосистемою. Країни СС та США зараз перебувають на другому етапі. Джерела РГЕ і локальна енергосистема стають рівноправними учасниками процесу забезпечення споживача електричною енергією. Проходять процеси організації взаємодії між основною енергосистемою і РГЕ під час управління енергосистемою. Знаходять рішення проблеми спільної підтримки параметрів напруги у споживача, оптимізації втрат. На роздрібному ринку електроенергії починає діяти конкуренція.

Третій етап - створення дисперсної енергосистеми, де значна частина енергії виробляється системами розподіленої генерації. Основною метою інтеграції РГЕ в енергосистему $є$ підвищення надійності електропостачання, зменшення втрат електроенергії та екологічного навантаження на довкілля. Водночас поява джерел РГЕ призводить до виникнення технічних проблем щодо організації їх роботи в енергосистемі, як-от забезпечення надійності та стійкості роботи, якості електроенергії, організації диспетчерського управління, зокрема виведення джерел РГЕ на паралельну роботу з енергосистемою та контролю відокремлення РГЕ від енергосистеми. При цьому підлягають розв'язанню можливі проблеми в електричних мережах середньої та низької напруги, зважаючи на появу двонаправлених перетікань електроенергії та необхідності обмеження струмів короткого замикання [11].

Для України під час реалізації завдань щодо широкомасштабного використання енергії відновлюваних джерел для РГЕ дуже важливим $\epsilon$ встановлення енергетичного потенціалу кожного 3 видів ВДЕ на всій території України. Для цього треба сформувати єдину інформаційно-аналітичну систему з розширеними функціями, яка дозво- лить оперативно вирішувати питання ефективності впровадження енергетичного обладнання в конкретній місцевості. До головних складників відновлюваної енергетики України належать: вітроенергетика, сонячна енергетика, мала гідроенергетика, біоенергетика, геотермальна енергетика й енергетика довкілля (використання теплових насосів). Потенціал відновлюваної енергетики в Україні наведені в Таблиці 1 [12].

Потенціал сонячної енерхії в Украйні. За метеорологічними даними надходження сонячної радіації визначено питомі енергетичні показники сонячної енергії та розподіл енергетичного потенціалу сонячного випромінювання для України. Річний технічно-досяжний енергетичний потенціал сонячної енергії в Україні є еквівалентним 4,2 млн т н.е., а його використання дозволяє заощадити біля 5 млрд м ${ }^{3}$ природного газу.

Середньорічна кількість сумарної сонячної радіації, що надходить на $1 \mathrm{~m}^{2}$ поверхні на території України, перебуває в межах від 1070 кВт ·од./ ${ }^{2}$ у північній частині України [12].

Потенціал енерхії вітру в Украӥні. Україна має досить великі ресурси вітрової енергії. Річний технічно-досяжний енергетичний потенціал енергії вітру в Україні є еквівалентним 10,5 млн т н.е., а його використання дозволяє щорічно заощаджувати біля 13 млрд $\mathrm{m}^{3}$ природного газу. За оцінками українських експертів, вітровий енергетичний потенціал дозволяє на території України економічно ефективно функціонувати вітровим електростанціям (далі - ВЕС) загальною потужністю 16000 МВт (не враховуючи офшорні ВЕС). В умовах України за допомогою вітроустановок можливим є використання $15 \div 19 \%$ річного обсягу енергії вітру, що проходить крізь перетин поверхні вітроколеса. Очікувані обсяги виробництва елек-

Таблиця 1

Потенціал відновлюваної енергетики в Україні

\begin{tabular}{|c|c|c|c|}
\hline \multirow{2}{*}{ № } & \multirow{2}{*}{ ВДЕ } & \multicolumn{2}{|c|}{ Річний технічно-досяжний потенціал } \\
\hline & & млрд. кВт*год./рік & млн. т н.е./рік \\
\hline 1 & Вітроенергетика & 60 & 15 \\
\hline 2 & Сонячна енергетика, зокрема: & 38,2 & 4,2 \\
\hline 2.1 & - електрична & 5,7 & 1,4 \\
\hline 2.2 & - теплова & 32,5 & 2,8 \\
\hline 3 & Велика гідроенергетика & 20,1 & 4,9 \\
\hline 4 & Мала гідроенергетика & 8,6 & 2,1 \\
\hline 5 & Біоенергетика, зокрема: & 178 & 21,7 \\
\hline 5.1 & - електрична & 27 & 7,21 \\
\hline 5.2 & - теплова & 151 & 14,49 \\
\hline 6 & Геотермальна теплова енергетика & 97,6 & 8,4 \\
\hline 7 & Енергія довкілля & 146,3 & 12,6 \\
\hline \multicolumn{2}{|c|}{ Загальні обсяги заміщення традиційних ПЕР } & 548,8 & 68,9 \\
\hline
\end{tabular}


троенергії 31 м² перетину площі вітроколеса у перспективних регіонах становлять

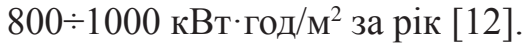

Енергетичний потенціал малих річок Украӥни. Згідно із Законом України № 601-VI до малих гідроелектричних станцій (далі - ГЕС) зараховують станції, що виробляють електричну енергію в результаті перетворення механічної енергії потоку води в електроенергію, встановлена потужність яких не перевищує 10 МВт.

Потенційні можливості малої гідроенергетики України на найближчу перспективу на період до 2030 року оцінені в Енергетичній стратегії на рівні 1147 МВт потужності з річним обсягом виробництва електроенергії 3,75 млрд. кВт год./рік [10].

Потенціал геотермальної енергії в Украӥні. Геотермальні ресурси України становлять термальні води і тепло нагрітих сухих гірських порід. Річний технічно-досяжний енергетичний потенціал геотермальної енергії в Україні є еквівалентним 8,4 млн т н.е., а його використання дозволяє заощадити біля 10 млрд м $^{3}$ природного газу.

Найбільш поширеним i придатним нині для технічного використання джерелом геотермальної енергії в Україні є геотермальні води. Затверджені Міністерством екології та природних ресурсів України потенційні геотермальні ресурси теплоенергетичних вод становлять 27,3 млн м³/добу, а їх теплоенергетичний потенціал - біля 84 млн Гкал/рік [12].

Енергетичний потенціал твердої біомаси, рідкого біопалива та біогазу в Украйні. Річний технічно-досяжний енергетичний потенціал твердої біомаси в Україні $є$ еквівалентним 18 млн т н.е., а його використання дає змогу щорічно заощаджувати близько 22 млрд м ${ }^{3}$ природного газу. Найбільший потенціал твердої біомаси зосереджений у Полтавській, Дніпропетровській, Вінницькій та Кіровоградській областях і становить понад 1,0 млн т н.е./рік.

На 14 підприємствах олійної промисловості спалюється понад 500 тис. т лушпиння соняшнику і 120 тис. т його гранулюється. Лісистість території України становить близько 16\% ії загальної площі. Щорічно заготовлюється 16-17 млн м ${ }^{3}$ ділової деревини; відходи переробки деревини становлять до 10 млн м³. Нині близько $70 \%$ відходів деревини у вигляді тирси, трісок, пелет і брикетів використовується як біопаливо [12].

Річний технічно-досяжний енергетичний потенціал рідкого біопалива в Україні є еквівалентним 1 млн т н.е. Його використання дає змогу щорічно заощаджувати близько 1,2 млрд м ${ }^{3}$ природного газу. Найбільший потенціал рідкого біопалива зосеред- жений у Вінницькій та Полтавській областях, де він становить понад 90 тис. т н.е./рік.

Річний технічно-досяжний енергетичний потенціал біогазу в Україні становить 2,3 млн т н.е. Його використання дозволяє щорічно заощаджувати біля 2,8 млрд м ${ }^{3}$ природного газу. Найбільший потенціал біогазу зосереджений у Дніпропетровській, Донецькій та Київській областях і становить понад 150 тис. т н.е./piк.

Ефективним шляхом доповнення та заміни традиційних ПЕР $є$ виробництво та використання біогазу, який утворюється в результаті застосування технологій метанового зброджування тваринницької біомаси і на $60-70 \%$ складається 3 метану. Іншим джерелом біогазу є звалища сміття на полігонах твердих побутових відходів [12].

Аналіз сучасних положень законодавчої бази в альтернативній енергетиці. ДП «НЕК Укренерго» відповідно до Закону України від 13.04.2017 р. «Про ринок електричної енергії» розробило «План розвитку системи передачі на 2019-2028 роки», який ураховує особливості майбутнього розвитку ОЕС України та містить низку заходів із підготовки до вирішення проблем безпеки постачання електроенергії на середньострокову та довгострокову перспективи [13].

На виконання ухваленого в жовтні 2012 р. Рішення Ради Міністрів Енергетичного Співтовариства D/2012/04/MC-EnC Про впровадження Директиви 2009/28/ЕС про заохочення до використання енергії, виробленої 3 відновлюваних джерел, розпорядженням Кабінету Міністрів України від 01.10.2014 p №902-р затверджено Національний план дій із відновлюваної енергетики на період до 2021 року (далі - НПД ВЕ) та План заходів із реалізації Національного плану дій із відновлюваної енергетики на період до 2021 року [14].

Головною метою НПД ВЕ є доведення до 2021 р. частки енергії, отриманої з поновлюваних джерел енергії у кінцевому енергоспоживанні країни до 11\%, що дозволить до 2021 р. зменшити використання традиційних первинних енергоресурсів в обсязі 8,6 млн т н.е. або 9,2 млрд м³ природного газу $[15 ; 16]$.

В Україні створено сприятливі умови для розвитку поновлюваної енергетики: «зелений» тариф розраховується відповідно до курсу євро; «зелений» тариф для електроенергії з біомаси та біогазу збільшено на 10\%; відсутні вимоги до «місцевого» складника; інвестор отримує надбавку до «зеленого» тарифу до $+10 \%$ за українське обладнання; введено «зелений» тариф для геотер- 
мальних електроустановок та сонячних і вітрових електростанцій приватних домогосподарств потужністю до 30 кВт; передбачено підписання довгострокових договорів купівлі-продажу електроенергії за «зеленим» тарифом з гарантованим покупцем до 2030 р. [17-19].

В Україні розроблено та запроваджено відповідне законодавство з альтернативної енергетики, зокрема Закони України:

- від 04.06.2015 р. № 514-VIII «Про внесення змін до деяких законів України щодо забезпечення конкурентних умов виробництва електроенергії 3 альтернативних джерел енергії», яким скасовано вимоги до «місцевої» складової; запроваджено «зелений» тариф для геотермальних електроустановок, для СЕС і ВЕС приватних домогосподарств потужністю до 30 кВт та введено надбавку до «зеленого» тарифу за дотримання рівня використання обладнання українського виробництва [20; 21].

Формування «зеленого» тарифу проводиться відповідно до курсу євро. За 2015-2017 рр. в Україні більше 3 тис. приватних домогосподарств встановили сонячні панелі загальною потужністю 51 МВт з інвестуванням майже $€ 52$ млн.;

- від 01.11.2016 р. № 1711-VIII «Про внесення змін до Закону України «Про альтернативні джерела енергії» щодо віднесення теплових насосів до обладнання, яке використовує відновлювані джерела енергії» приведено у відповідність до Директиви 2009/28/СС визначення «альтернативні джерела енергії», «гідротермальна», «геотермальна» та «аеротермальна» енергія;

- від 05.12.2017 р. №2222-19 «Про приєднання України до Статуту Міжнародного агентства 3 відновлювальних джерел енергії (IRENA)» сприятиме виконанню міжнародних зобов'язань щодо виробництва у 2020 р. $11 \%$, а у 2035 р. - до $25 \%$ «чистої» енергії з поновлюваних джерел в енергетичному балансі [22; 25].

Законопроектом України від 07.06.2018 р. № 8449 «Про внесення змін до деяких законів України щодо забезпечення конкурентних умов виробництва електричної енергії 3 альтернативних джерел енергії» передбачено, починаючи з 01.07.2019 р., запровадити новий порядок надання державної підтримки об' єктам електроенергетики, що виробляють електроенергію 3 енергії сонця або вітру, для СЕС - об'єкти встановленої потужності більше 10 МВт, для ВЕС більше $20 \mathrm{MB}$, які будуть введені в експлуатацію після 01.07.2019 р. Такі об'єкти набувають права на державну підтримку на аукціоні з розподілу квоти державної підтримки. Нові інвестори матимуть можливість отримувати «зелений» тариф на умовах аукціону, який буде діяти не до 2030 p, а протягом 20 років із моменту введення об'єкта в експлуатацію.

Усі проекти меншої потужності будуть мати можливість вибору: працювати до 2030 р. за «зеленим» тарифом або працювати за тарифом, який визначається на аукціоні [23].

За даними Держенергоефективності Міністерством закордонних справ Фінляндії і Північної екологічної фінансової корпорації NEFCO підписано 29.11.2017 р. Угоду про створення цільового фонду для фінансування поновлюваної енергетики в Україні. Фінсько-українським цільовим фондом передбачено надання технічної допомоги і виокремлення грантових коштів обсягом €6 млн для реалізації проектів «чистої» енергетики в Україні. Сьогодні NEFCO вже профінансовано близько 150 проектів у сфері поновлюваної енергетики та енергоефективності в Україні.

Міненерговугілля України 27.02.2018 p. підписано 3 Міністерством закордонних справ Королівства Данія Угоду про продовження співробітництва у сфері розвитку та діяльності Українсько-Данського енергетичного центру (Угода від 22.12.2014 р. № 208_029) щодо сприяння у формуванні сприятливого середовища для залучення інвестицій у сталий розвиток енергетики України, досягнення цілей Стратегії ЕСУ-2035 щодо доведення частки $11 \%$ поновлювальної енергії у кінцевому енергоспоживанні до 2020 р. та 25\% до 2035 р.; підвищення енергоефективності та енергонезалежності, а також допомога в імплементації Національного плану дій з енергоефективності до 2020 року і в розробці та виконанні нового Національного плану дій з енергоефективності до 2035 року та Національного плану дій із відновлюваної енергетики до 2035 року; стимулюванні енергоефективності для промисловості тощо [24; 25].

Висновки. Світовий досвід розвитку систем розподіленої генерації говорить про можливість побудови надійних систем електропостачання на основі альтернативних поновлюваних джерел живлення. Проаналізовано енергетичний потенціал первинних джерел енергії для використання альтернативними джерелами генерації. Проаналізовано нормативно-правову базу зі сприяння розвитку альтернативної енергетики в Україні. 


\section{Список літератури:}

1. World survey of decentralized energy 2005. WADE, Edinburgh, 2004. 45 p.

2. Ackermann T., Anderson G., Soeder L. Distributed generation: a definition / Electric Power Systems Research, 2001, Vol. 57, p. 195-204.

3. Кейко А.В. Становление прогнозных технологических исследований в энергетике. / Системные исследования в энергетике. Ретроспектива научных направлений СЭИ-ИСЭМ. Новосибирск: Наука, 2010. C. $127-146$.

4. Воропай Н.И., Кейко А.В., Клер А.М., Стенников В.А Технико-экономические проблемы использования нетрадиционной энергетики / Проблемы нетрадиционной энергетики. Материалы науч. сессии През. СО РАН,13.12.2005. Новосибирск: Изд-во СО РАН, 2006. С. 32-54.

5. Кейко А.В. Системное сопоставление энергетических технологий / Системные исследования в энергетике. Ретроспектива научных направлений СЭИ-ИСЭМ. Новосибирск: Наука, 2010. С. 215-227.

6.Стенников В.А., Воропай Н.И. Централизованная и распределенная генерация - не альтернатива, а интеграция. Известия РАН. Энергетика. № 1. С. 64-73.

7. Hansen C.J., Bower J. An economic evaluation of small-scale distributed electricity generation technologies. Oxford Institute for Energy Studies \& Dept. of Geography, Oxford University, 2004. 59 p.

8. Bauen A., Hawkes A. Decentralised generation - technologies and market perspectives. IEA, Paris, 2004. 18 p.

9. Мировой опыт автономного энергоснабжения для российской глубинки. URL: https:/gisee.ru/ regionsupport/articles/reg_programs/54702/ (дата звернення: 20.03.2021)

10.Розподілена генерація електроенергії - глобальні тенденції розвитку. URL: http:/uare.com.ua/ novyny/453-rozpodilena-generatsiya-elektroenergiji-globalni-tendentsiji-rozvitku.html (дата звернення: $02.03 .2021)$

11. Лежнюк П.Д., Ковальчук О.А., Нікіторович О.В., Кулик В.В. Відновлювані джерела енергії в розподільних електричних мережах: монографія . Вінниця : ВНТУ, 2014. 204 с.

12. Кудря С.О. Потенціал розвитку нетрадиційних і відновлюваних джерел енергії. Модуль 23. Київ : ЮНІДО, 2015. С. 19.

13. Законодавчі ініціативи у сфері альтернативної енергетики. Держенергоефективності. Презентація. 2017. 24 стор. URL: www.saee.gov.ua. (дата звернення: 09.03.2021)

14. Михайлов М.П. Звіт про виконання Угоди про Асоціацію між Україною та Європейським Союзом у 2017 році . Урядовий офіс координації європейської та євроатлантичної інтеграції, Офіс Віцепрем'єрміністра $з$ питань європейської та євроатлантичної інтеграції України спільно з експертами Проекту Європейського Союзу «Association4U». Київ. 2018. 88 c. URL: http:www.eu-ua.org. «Зеленая» оптимизация. Энергобизнес. 2018. №23. С.18-20 (дата звернення: 02.02.2021)

15. Ковальчук В.В. Интеграция ОЭС Украины с ENTSO-E может снизить цены на э/э в стране на 20 - 30\%. Интерфакс-Украина. 2017. URL: https://interfax.com.ua/news/economic/437118.html. (дата звернення: 12.12.2020)

16. Механізми фінансування заходів енергоефективності в Україні. Мінрегіон Украӥни. 2017. 64 стор. URL: http://es.esco.agency/images/art/3-2017/art20.pdf (дата звернення: 20.03.2021)

17. Дячук О.А. Перехід України на відновлювану енергетику до 2050 року. Презентаиія. 2017. 29 с. URL: https://www.energybrainpool.com/fileadmin/download/Studien/Studie_20170626 (дата звернення: 20.03.2021)

18. Пріоритетнізаходи для зменшення споживання природного газу в України (до 2022 року). Держенергоефективності. Презентація. 2017. 20 стор. URL: http://saee.gov.ua/sites/default/files/EfWconcept_15_02_2018. pdf (дата звернення: 25.03.2021)

19. Програми утеплення житла: державна і місцева підтримка у 2017 p. Держенергоефективності. Презентаиія. URL: http://saee.gov.ua/sites/default/files/Final_Savchuk_2017.pdf (дата звернення: 28.03.2021)

20. Савчук С.Д. Результати урядової політики скорочення споживання енергії та плани на найближчий період. Презентаиія. 2018. 10 стор. URL: http://saee.gov.ua/sites/default/files/SAEE (дата звернення: 25.03.2021)

21. Савчук С.Д. Розбудова сфери енергоефективності та відновлюваної енергетики в Україні: здобутки 2017 р. Презентаиія. 2017. 41 стор. URL: http://www.saee.gov.ua. (дата звернення: 29.03.2021)

22. Україна у співпраці з IRENA залучатиме досвід та інвестиції провідних країн світу у вітчизняну відновлювану енергетику. Держенергоефективності. Презентація. 2018. URL: http://www.saee.gov.ua/ uk/news/2148. (дата звернення: 29.03.2021)

23. Ковальчук В.В. Укренерго-2017: Результати перших реформ. Енергетика та електрифікаиія. 2017. C. $10-13$.

24. Михайлов М.П. «Укренерго» подводит итоги. Энергобизнес. 2018. № 7. С. 18-19.

25. Укренерго - за розвиток самодостатньої «зеленої» генерації. URL: http:www.ukrenergo.energy.gov.ua (дата звернення: 29.03.2021) 


\section{Chernyuk A.M., Kirisov I.G., Cherevik Yu.O. ANALYSIS OF PROSPECTS FOR THE DEVELOPMENT OF DISTRIBUTED GENERATION OF ELECTRICITY GENERATION IN UKRAINE}

The article considers the current trends in the development of world and domestic energy, the current state and directions of development of distributed generation systems based on alternative power sources.

The problems that arise during the construction of power supply systems with distributed generation are analyzed. The application of RGE may be affected by the following restrictions: the supply of natural gas, the density of electrical and thermal loads, the stability of the power system. The possibility of introducing distributed energy generation determines its competitiveness in relation to centralized systems and in this perspective depends on many factors: the level of tariffs for connection to electricity and heat networks; principles of formation of tariffs for electricity and heat, and more precisely - from the ratio of tariffs for electricity and heat and the cost of fuel; practical implementation of measures for non-discriminatory access to the electricity grid and natural gas supplies; development of the power equipment market (including its maintenance); the pace of economic development of the country as a whole and specific regions; protectionist policy of the state.

The world experience in construction and operation of electric networks with distributed generation is analyzed. At present, in many countries of the world, along with the development of centralized energy supply, the trend of large-scale transition to EWG, which has the advantage of greater competitiveness, is increasingly supported.

Possibilities of energy potential of energy carriers of RGE systems in Ukraine are analyzed. For Ukraine, in the implementation of tasks related to the large-scale use of renewable energy for $R G E$, it is very important to establish the energy potential of each type of RES throughout Ukraine.

The regulatory framework in the field of implementation and support of environmentally friendly electricity generation in Ukraine is analyzed.

Key words: distributed generation, Smart Grids, energy carriers, energy potential, alternative energy sources, "green" tariff. 